\title{
PERANCANGAN SISTEM INFORMASI AKADEMIS PERGURUAN TINGGI BERBASIS DATA DIKTI/EPSBED
}

\author{
Karto Iskandar; Reina; Irma Irawati Ibrahim \\ Computer Science Department, School of Computer Science, Binus University \\ Jl. K.H. Syahdan No. 9, Palmerah, Jakarta Barat 11480 \\ karto_i@binus.edu, reina@binus.edu, irma.irawati@binus.edu
}

\begin{abstract}
This research aims to help universities that do not have an academic information system and facilitate EPSBED data report to Directorate of Higher Education (DHE). The method used is the three first stages in the System Development Life Cycle (SDLC), which are systems engineering, requirements analysis, and design system. The result is a design of university business process, design of database, and design of user interface. This research finds that DHE has a specific data structure that can represent the basic activities of a study program. Therefore, this system design can be used for reporting of EPSBED data as well as for data collection of study program activities.
\end{abstract}

Keywords: academic business process, academic information system design, higher education, EPSBED

\begin{abstract}
ABSTRAK
Penelitian ini bertujuan membantu perguruan tinggi yang belum memiliki sistem informasi akademik dan mempermudah pelaporan data EPSBED kepada Direktorat Jendral Pendidikan Tinggi (DIKTI). Metode penelitian yang digunakan adalah tiga tahapan awal dalam System Development Life Cycle (SDLC), yaitu system engineering, requirement analysis, dan design system. Hasil penelitian ini berupa rancangan bisnis proses sebuah perguruan tinggi, rancangan database yang dipakai, dan rancangan user interface. Dalam penelitian ini ditemukan bahwa DIKTI memiliki struktur data tertentu yang dapat mewakili aktifitas dasar dari sebuah program studi. Oleh karena itu, perancangan ini selain untuk pelaporan EPSBED, juga dapat digunakan untuk pendataan aktifitas dasar program studi.
\end{abstract}

Kata kunci: proses bisnis akademik, perancangan sistem informasi akademik, pendidikan tinggi, EPSBED 


\section{PENDAHULUAN}

Peningkatkan kualitas sumber daya manusia Indonesia tentunya tidak terlepas dari faktor pendidikan formal yang ada. Bermunculannya universitas, sekolah tinggi, akademi di Indonesia harus disambut positif karena akan membuka kesempatan seluas-luasnya bagi masyarakat untuk mengenyam pendidikan di tingkat yang lebih tinggi. Iklim persaingan akan tercipta dengan sendirinya untuk merebut pangsa pasar dengan meningkatkan kualitas dari masing-masing perguruan tinggi.

Sejalan dengan peningkatan kualitas, pemerintah dalam hal ini DIKTI berperan untuk menetapkan aturan yang akan menjaga kualitas dari perguruan tinggi yang ada. Standar yang ditetapkan tentunya sudah dirancang dan dikaji dengan matang guna menjadi acuan untuk keberlangsungan program studi di semua perguruan tinggi. Melalui Evaluasi Program Studi Berdasarkan Evaluasi Diri (EPSBED), pemerintah berusaha untuk mengawal perguruan tinggi agar tetap berada pada koridor tepat yang telah digariskan.

Salah satu sistem informasi yang ada di perguruan tinggi adalah sistem informasi akademik. Dalam sistem informasi akademik ini tidak hanya mencakup sistem proses belajar mengajar saja, tetapi mencakup semua proses dari mulai seleksi calon mahasiswa sampai pelacakan lulusan. Keluaran dari sistem informasi ini diharapkan dapat memberikan informasi yang relevan dan up to date bagi stakeholder (calon mahasiswa, dosen, mahasiswa, administrasi, pengguna lulusan) (Wardana, 2010, p.6).

Sistem Informasi Akademik adalah perangkat lunak yang digunakan untuk menyajikan informasi dan menata administrasi yang berhubungan dengan kegiatan akademis. Dengan penggunaan perangkat lunak seperti ini diharapkan kegiatan administrasi akademis dapat dikelola dengan baik dan informasi yang diperlukan dapat diperoleh dengan mudah dan cepat. Sistem Informasi Akademik yang bersifat online memudahkan sivitas akademika untuk mengakses informasi berkaitan dengan kebutuhan akademis. Informasi dapat diakses dari komputer mana saja yang tersambung dengan jaringan kampus bila diketahui nama akun dan kata sandi yang dibutuhkan (Satoto, 2009, p.3).

Tidak dapat dipungkiri bahwa saat ini pemanfaatan teknologi informasi pada perguruan tinggi di Indonesia belum merata. Dimana masih ada perguruan tinggi yang belum memanfaatkan teknologi infomasi secara optimal, hal ini dapat menjadi kendala dalam pelaporan EPSBED. Diyakini dengan menggunakan teknologi informasi dapat mempermudah dan mempercepat pengolahan data dan penyajian informasi.

Belum optimalnya pemanfaatan teknologi informasi dari masing-masing perguruan tinggi tentunya menciptakan beberapa kendala dalam melakukan operasional akademis dan pembuatan Laporan EPSBED, seperti: (1) Proses manual yang masih dilakukan di beberapa perguruan tinggi; (2) Banyaknya data atau informasi yang harus dikelola dan dilaporkan; (3) Data yang belum terintegrasi antar unit yang mengelola operasional akademis; (4) Struktur data operasional akademis yang berbeda dari standar yang ditentukan DIKTI dalam pelaporan EPSBED. Kondisi ini menimbulkan beberapa permasalahan dalam pembuatan laporan EPSBED, yaitu: (1) kesulitan dalam pengumpulan data-data akademis; (2) akurasi data yang dikumpulkan tidak terjaga dengan baik; (3) membutuhkan waktu yang lebih lama dalam mengolah data dan membuat laporan. Melihat kondisi tersebut, dilakukan penelitian untuk mengembangkan sebuah sistem informasi guna mengolah kegiatan akademis pada sebuah perguruan tinggi berbasis data DIKTI yang akan dilaporkan dalam EPSBED dengan berlandaskan beberapa teori Rekayasa Piranti Lunak.

Sistem Informasi Manajemen Pendidikan merupakan sistem komputerisasi manajemen yang mengelola administrasi akademik yang meliputi pemasukan data, pengolahan, dan editing data, serta 
otomasi pelaporan. Dalam penelitian ini dicoba untuk membangun sebuah Sistem Informasi Manajemen Pendidikan yang mencakup administrasi akademik dan ruang dengan basis spasial yang diwujudkan dalam sebuah aplikasi komputer client-server, mulai dari pembangunan basis data, perancangan sistem hingga implementasi sistem. Dengan dikembangkannya SIM-PT ini dapat menjadi alat dalam mengelola dan mencari informasi akademik secara efektif dan efisien.

Tujuan yang ingin dicapai dari penelitian ini adalah sebagai berikut: (1) Mengidentifikasi dan mengumpulan informasi mengenai sistem basis data DIKTI dalam pelaporan EPSBED; (2) Mengidentifikasi dan mengumpulkan proses bisnis dalam dunia pendidikan khususnya area operasional akademis perguruan tinggi secara umum di Indonesia; (3) Melakukan analisis dan perancangan sistem informasi yang dibutuhkan oleh perguruan tinggi dalam menunjang proses operasional akademis dengan menggunakan sistem basis data DIKTI / EPSBED.

Pada penelitian kali ini, peneliti akan mengacu kepada beberapa jurnal dan artikel yang sudah ada sebelumnya yang terkait dengan pengembangan sistem informasi perguruan tinggi dan sistem informasi terkait pelaporan EPSBED. Untuk saat ini jurnal yang telah diperoleh adalah Perancangan Sistem Informasi Akademik (SIM PT) Berbasis Database EPSBED oleh Wardana dari Universitas Muhammadiyah Buton tahun 2010 dan Analisis Keamanan Sistem Informasi Akademik Berbasis Web di Fakultas Teknik Universitas Diponegoro oleh Kodrat Iman Satoto dari Universitas Diponegoro tahun 2009.

\section{METODE}

Penelitian akan dilakukan dengan menggunakan metodologi SDLC (Bennett, 2002, p.48). SDLC merupakan sebuah pendekatan sistematik (systematic approach) sebagai pemecahan masalah dan dikomposisi dalam beberapa fase. Hanya tiga tahapan yang dilakukan: (1) system engineering pada tahap ini akan dilakukan identifikasi atas kebutuhan utama dari keseluruhan sistem dan kemudian identifikasi bagian-bagian dari sistem yang akan diimplementasikan; (2) requirement analysis - pada tahap ini akan dilakukan pengumpulan data dan informasi yang dibutuhkan, dengan melakukan studi pustaka dan observasi. Kemudian dilakukan analisis dari kebutuhan; (3) design - pada tahap ini akan dibuatkan perancangan bisnis proses operasional akademik, perancangan database dengan diagram hubungan antar tabel dan perancangan User interface. Sedangkan tahapan construction, testing, installation dan maintenance tidak dilakukan dalam penelitian ini karena dalam penelitian ini hanya membahas analisis dan perancangan sistem informasi.

\section{HASIL DAN PEMBAHASAN}

\section{Perancangan Proses Bisnis}

\section{Admisi}

Proses awal penerimaan mahasiswa adalah melalui proses admisi. Calon mahasiswa mengikuti serangkaian proses mulai dari membeli formulir pendaftaran, mengikuti tes seleksi, dan melakukan pembayaran. Pada proses pengisian formulir pendaftaran, informasi yang dibutuhkan antara lain adalah jenjang, program studi, nama, jenis kelas (regular atau non regular atau kerja sama), tempat dan tanggal lahir, jenis kelamin, dan informasi asal pendidikan sebelumnya. Penerimaan mahasiswa baru terbuka pula bagi mahasiswa pindahan dari perguruan tinggi lain. Untuk mahasiswa pindahan diperlukan informasi asal perguruan tinggi, program studi, dan jumlah SKS pindahan. 
Sebelum dilakukan proses penerimaan mahasiswa baru, perlu dibuat perencanaan kapasitas yang dapat menampung jumlah mahasiswa baru. Data yang perlu disiapkan adalah jumlah target mahasiswa (daya tampung), jumlah calon pendaftar ikut seleksi, jumlah calon dinyatakan lulus seleksi, jumlah mendaftar sebagai mahasiswa, jumlah mahasiswa mengundurkan diri karena diterima di UMPTN/SPMB/perguruan tinggi lain, dan jumlah mahasiswa baru status pindahan.

\section{Perkuliahan}

Proses perkuliahan meliputi berbagai kegiatan, yaitu aktifitas kuliah mahasiswa, nilai mahasiswa, aktifitas status mahasiswa, dan aktifitas mengajar dosen. Penjelasan dari masing-masing aktifitas, sebagai berikut:

Aktifitas kuliah mahasiswa - untuk mengetahui aktifitas perkuliahan seorang mahasiswa, kita perlu memiliki beberapa data sehubungan dengan kegiatan mahasiswa. Informasi mengenai jenjang dan program studi yang diambil mahasiswa tertentu, kode mahasiswa, nama mahasiswa, total sks yang sudah dilalui per semester dan total, IPS, dan IPK. Informasi ini akan dapat dimanfaatkan baik bagi pihak universitas, dikti, maupun mahasiswa itu sendiri.

Nilai semester mahasiswa - keberhasilan studi dari seorang mahasiswa terlihat dari nilai-nilai yang diperoleh dari setiap mata kuliah yang telah dilalui. Informasi sehubungan dengan nilai mahasiswa harus dimiliki meliputi kode mahasiswa, nama mahasiswa, kode dan nama mata kuliah, nilai, dan bobot untuk perhitungan nilai. Bobot diisi dengan bobot dari nilai yang digunakan sesuai dengan ketentuan yang ada pada masing-masing program studi, misalnya: $A=4, B=3, C=2, D=1$, dan $\mathrm{E}=0$, dan lain-lain. Pada akhirnya dari informasi nilai inilah yang akan menghasilkan perhitungan IPS dan IPK dari seorang mahasiswa.

Aktifitas status mahasiswa - dalam perjalanannya mahasiswa dapat memiliki beberapa status akademik. Mahasiswa yang memiliki jadwal kuliah mereka dapat dikatakan sebagai mahasiswa aktif. Mahasiswa juga berhak mengajukan cuti akademik jika mereka tidak menginginkan kuliah pada semester tertentu, mahasiswa tersebut harus didatakan status akademiknya sebagai 'cuti'. Bagi mahasiswa yang tidak mengajukan cuti maupun mendaftar ulang untuk menjalani semester berikutnya dimana status mahasiswa tidak jelas, status akademisnya dapat digolongkan 'non-aktif'. Mahasiswa yang tidak aktif untuk kurun waktu tertentu sehingga masa studinya sudah habis atau alasan-alasan lainnya yang dapat mengakibatkan status akademiknya menjadi 'drop out' (DO). Mahasiswa juga dapat mengajukan pengunduran diri dari sebuah perguruan tinggi. Pada saat proses pengunduran diri sudah dilakukan, status mahasiswa tersebut diubah menjadi 'mengundurkan diri'. Status lainnya adalah bagi mahasiswa yang telah berhasil menyelesaikan masa studinya dikatakan sebagai mahasiswa yang sudah lulus statusnya akan diubah menjadi 'lulus' yang selanjutnya disebut 'alumni'.

Aktifitas mengajar dosen - selain aktifitas belajar mahasiswa, informasi aktifitas mengajar dosen juga harus dimiliki oleh sebuah perguruan tinggi. Informasi ini akan digunakan untuk melakukan penjadwalan proses belajar mengajar, melihat histori mengajar dosen, dan lain-lain. Aktifitas mengajar dosen dapat diketahui dengan beberapa informasi berikut kode dan nama dosen, kode dan nama mata kuliah yang diajar dosen, kode dan nama kelas, jumlah rencana tatap muka sebuah mata kuliah yang akan diajarkan oleh dosen, dan realisasi mengajar yang dinyatakan oleh berapa jumlah tatap muka yang telah dilakukan oleh dosen.

Alumni - hasil lulusan dari sebuah perguruan tinggi. Beberapa informasi yang harus didatakan yaitu tanggal lulus, SKS Lulus, IPK, nomor dan tanggal Surat Keterangan (SK) Yudisium dan Nomor seri Ijazah. SK Yudisium adalah surat keterangan yang dikeluarkan oleh rektor/ketua/direktur perguruan tinggi yang bersangkutan. Persiapan materi perkuliahan dan pembelajaran - kurikulum merupakan dasar kegiatan mahasiswa. Semua mata kuliah yang akan dipelajari mahasiswa di sebuah universitas berdasarkan kurikulum yang telah mereka pilih. Kurikulum ini juga yang akan membentuk 
kompetensi dari masing-masing mahasiswa setelah mereka lulus nanti. Kurikulum untuk setiap angkat masuk mahasiswa bisa sama dan berbeda. Untuk itu, kita memerlukan informasi pendataan sebuah kurikulum yang diberlakukan untuk angkatan masuk tertentu, biasanya informasi yang disimpan berupa tahun dan semester dimana kurikulum tersebut diterapkan serta keterangan program studi yang menerapkan kurikulum tersebut. Kurikulum terdiri dari perencanaan perkuliahan mahasiswa yang terdiri dari informasi mata kuliah apa saja yang harus diambil mahasiswa setiap semesternya. Untuk itu pendataan keterangan mata kuliah dan semester dimata mata kuliah itu akan diambil harus didatakan dalam pendataan kurikulum. Pada saat melakukan pendataan mata kuliah, informasi jumlah SKS juga harus didatakan karena jumlah sks inilah yang akan menentukan waktu pelajaran tersebut akan dilalui mahasiswa. Informasi sehubungan dengan SKS terdiri dari SKS Mata Kuliah, SKS Tatap Muka; SKS Praktikum, dan SKS Praktek Lapangan. Mengingat Sebuah mata kuliah tidak akan selamanya akan ditawarkan, perlu disiapkan informasi status dari sebuah mata kuliah apakah 'aktif' atau 'hapus' (mata kuliah tersebut tidak dipakai lagi terhitung mulai semester ini dan seterusnya). Berdasarkan kurikulum dan daftar mata kuliah yang ada, proses pembuatan materi perkuliahan dapat dilakukan. Banyak perguruan tinggi menyebutnya sebagai ‘silabus mata kuliah' yang biasanya berupa penjelasan untuk setiap pertemuan dan tujuan dari mata kuliah tertentu.

Administrasi dosen dan asisten, penelitian dan publikasi dosen, pengabdian kepada masyarakat - Untuk menghasilkan lulusan yang berkualitas tentunya perlu didukung oleh dosen yang berkualitas. Hal ini dimulai dari perekrutan dosen dengan memperhatikan latar belakang pendidikan yang sesuai dengan program studi yang ada. Untuk itu beberapa data riwayat pendidikan diperlukan mulai dari jenjang terendah setelah SMU adalah jenjang pendidikan, tanggal lulus/ijazah, gelar, perguruan tinggi (PT), kota asal PT, negara, dan bidang ilmu.

Dosen merupakan mitra bagi program studi dalam pelaksanaan kegiatan akademik. Setiap dosen wajib memiliki nomor induk dosen nasional (NIDN) di samping nomor dosen dari masingmasing institusi. Data-data dosen lain yang perlu disimpan adalah nama, jenjang program studi sesuai dengan homebase dosen, program studi sesuai pula dengan homebase, nomor KTP, gelar akademik, jenis kelamin, tempat lahir, tanggal lahir, status akhir (keluar/pensiun/almarhum, pendidikan tertinggi, jabatan akademik, ikatan kerja. Khusus pegawai negeri sipil diperlukan informasi tambahan yaitu: NIP, instansi induk yang merupakan kode dari perguruan tinggi, akta mengajar dan ijin mengajar.

Dalam perjalanan suatu institusi, tidak dapat dihindari bahwa setiap semester akan ada dosen dengan kondisi ikatan kerja yang terpaksa harus diakhiri secara permanen dengan alasan dosen pensiun, meninggal atau keluar atas permintaan dosen yang bersangkutan. Di samping dapat juga ikatan kerja dihentikan sementara karena dosen mengajukan cuti dengan alasan studi lanjut atau yang lainnya. Semua proses tersebut tentunya harus dapat diakomodir dan tercatat dengan baik. Untuk itu dibutuhkan data transaksi dosen cuti/keluar, yaitu periode yang terdiri dari tahun akademik dan semester, jenjang studi, program studi, nomor dosen, dan status dosen (studi lanjut, cuti, keluar/pensiun, dan menjabat di instansi lain).

Salah satu tugas seorang dosen sesuai dengan Tri Dharma perguruan tinggi adalah melakukan penelitian. Untuk itu informasi penelitian dan publikasi dosen sangat dibutuhkan, yaitu periode penelitian, nomor dosen, jenis karya Ilmiah, media publikasi, pelaksanaan, peran peneliti, jenis pembiayaan, tahun, bulan, dan judul karya ilmiah.

\section{Aktifitas Manajemen}

Penyelenggara perguruan tinggi yang sah harus memiliki ketetapan hukum yang jelas. Pada umumnya penyelenggara bernaung pada sebuah yayasan pendidikan. Yayasan pendidikan yang dimaksud harus memiliki akta pendirian dimana tercantum nomor akta dan tanggal pendirian serta pengesahan dari Pengadilan Negeri. Data terkait yang perlu dilaporkan adalah nama badan hukum, tanggal awal berdiri, alamat, kota, kode EOS, telepon, faks, e-mail, website, nomor akta terakhir, 
tanggal akta terakhir, nomor pengesahan pengadilan negeri (PN) atau lembar berita negara (LN), dan tanggal pengesahan PN atau LN.

Di samping data penyelenggara perguruan tinggi, data terkait perguruan tinggi juga perlu dilaporkan, seperti nama perguruan tinggi, tanggal awal berdiri, alamat, kota, kode pos, telepon, faks, e-mail, website, nomor akta atau SK Pendirian, dan tanggal akta atau SK.

Proses selanjutnya adalah pembukaan program studi. Semua program studi yang diselenggarakan harus terdaftar dan mendapatkan ijin operasional. Data penunjang terkait dengan program studi yang harus disiapkan adalah nama pimpinan, data tenaga non-akademik, tanggal berdiri program studi, e-mail, SKS lulus, status aktif atau tidaknya program studi, mulai semester tidak aktif atau ditutupnya program studi, nama ketua program studi, telepon ketua program studi, telepon sekretariat program studi, faks, nama operator pengelola program studi, telepon operator, nama program studi, frekuensi dan pelaksanaan pemutakhiran kurikulum, nomor dan tanggal SK Ijin Penyelenggaraan Program Studi dari DIKTI, nomor dan tanggal SK Akreditasi BAN-PT, dan status akreditasi.

Pengelola program studi bertanggung jawab atas kegiatan akademik di program studi masingmasing termasuk ketersediaan fasilitas penunjang kegiatan akademik. Ada dua kategori fasilitas, penunjang kegiatan akademik, yaitu fasilitas yang dimiliki oleh institusi dan fasilitas yang digunakan oleh program studi. Fasilitas yang digunakan oleh program studi bersama dengan program studi lain, maka data akan dihitung secara proposional berdasarkan data penggunaan riil. Data yang temasuk dalam fasilitas penunjang kegiatan akademik adalah luas tanah, luas kebun atau lahan percobaan, luas ruang kuliah, luas ruang laboratorium, luas ruang perpustakaan, jumlah judul buku, jumlah buku, luas ruang kegiatan ektra kurikulum mahasiswa, luas ruang pusat komputer, luas ruang seminar, luas ruang dosen, dan luas ruang administrasi kantor.

Beberapa proses bisnis perguruan tinggi di atas digambarkan dalam bentuk paling sederhana sebagai berikut (Gambar 1):

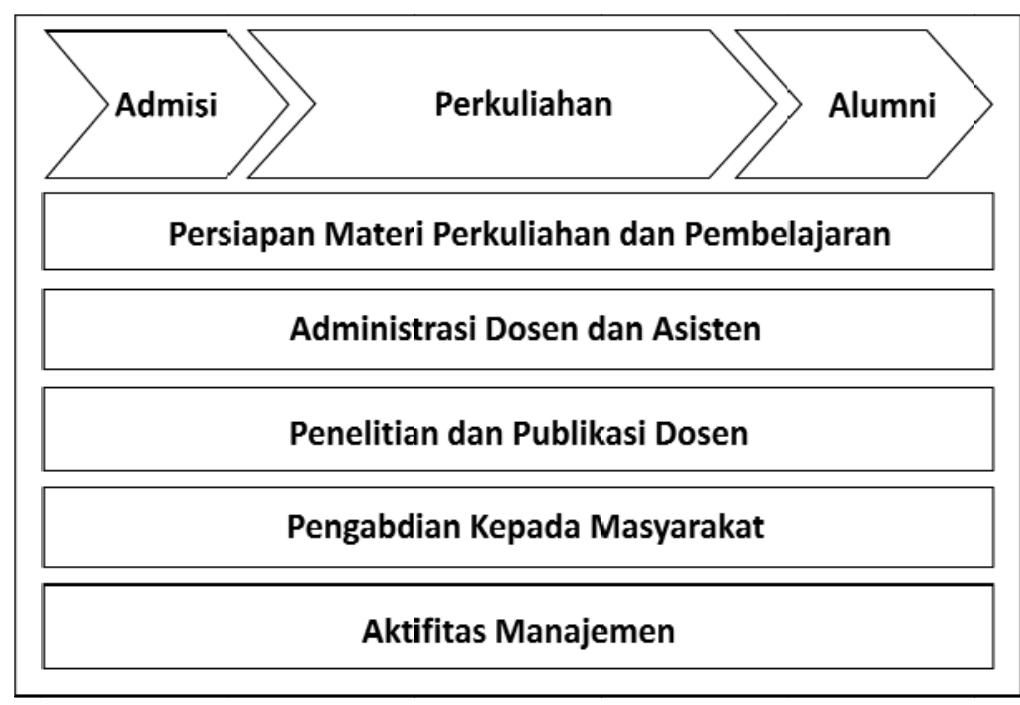

Gambar 1. Proses bisnis perguruan tinggi (data pelaporan DIKTI / EPSBED).

\section{Perancangan Database}

Setelah melakukan analisis terhadap data pelaporan DIKTI / EPSBED, maka 28 tabel yang 
ada dibagi ke dalam dua kelompok, yaitu: (1) kelompok yang tidak berhubungan atau tidak digambarkan dalam diagram ERD; (2) kelompok yang saling berhubungan satu tabel dengan tabel lain atau digambarkan dalam diagram ERD. Ada 8 tabel yang tidak saling berhubungan: Transaksi Nama Pimpinan dan Tenaga Non-akademi (TRPIM), Transaksi Hasil Isian Kuesioner (TRTES), Transaksi Laboratorium (TRLAB), Transaksi Isian Jawaban Pertanyaan (TRPPG), Tabel Perguruan Tinggi (TBPTI), Tabel Program Studi (TBPST), Tabel Kode Aplikasi (TBKOD), dan Tabel Propinsi (TBPRO). Selebihnya ada 20 tabel yang saling berhubungan. Tabel-tabel tersebut terhubung satu sama lain berdasarkan field yang saling berhubungan atau referensi dan digambarkan dalam satu diagram yang disebut $E R D$ (Gambar 2).

\section{Perancangan User Interface}

Setelah melakukan analisis terhadap data pelaporan DIKTI/EPSBED, minimal ada 19 modul yang yang harus ada di dalam sebuah Sistem Informasi Akademis, yaitu: Modul Pendataan Badan Hukum dan Perguruan Tinggi, Modul Master Program Studi, Modul Master Mahasiswa, Modul Master Dosen, Modul Pemindahan Homebase Dosen, Modul Master Riwayat Pendidikan Dosen, Modul Tabel Kurikulum, Modul Transaksi Aktifitas Kuliah Mahasiswa, Modul Transaksi Mahasiswa Lulus/Keluar/Non-aktif/Cuti, Modul Transaksi Aktifitas Mengajar Dosen, Modul Transaksi Dosen Keluar/Cuti/Studi Lanjut, Modul Transaksi Publikasi/Penelitian Dosen, Modul Fasilitas Penunjang Akademik, Modul Transaksi Kapasitas Mahasiswa, Modul Transaksi Nama Pimpinan dan Tenaga Non-akademik, Modul Evaluasi Semester, Modul Isian Program Studi Kependidikan, Modul Gabungan Data per Program Studi, dan Modul Pecah Data per Program Studi.

Dalam penelitian ini, penulis tidak menyertakan semua user Interaface (UI); hanya beberapa dari modul tersebut di atas, yaitu UI untuk: (1) Modul Pendataan Data Badan Hukum (Gambar 3); (2) Modul Pendataan Data Dosen (Gambar 4); (3) Modul Pendataan Data Mahasiswa (Gambar 5); (4) Modul Pendataan Data Mata Kuliah (Gambar 6); (5) Modul Pendataan Data Komponen Nilai (Gambar 7); (6) Modul Laporan IPK (Gambar 8). 


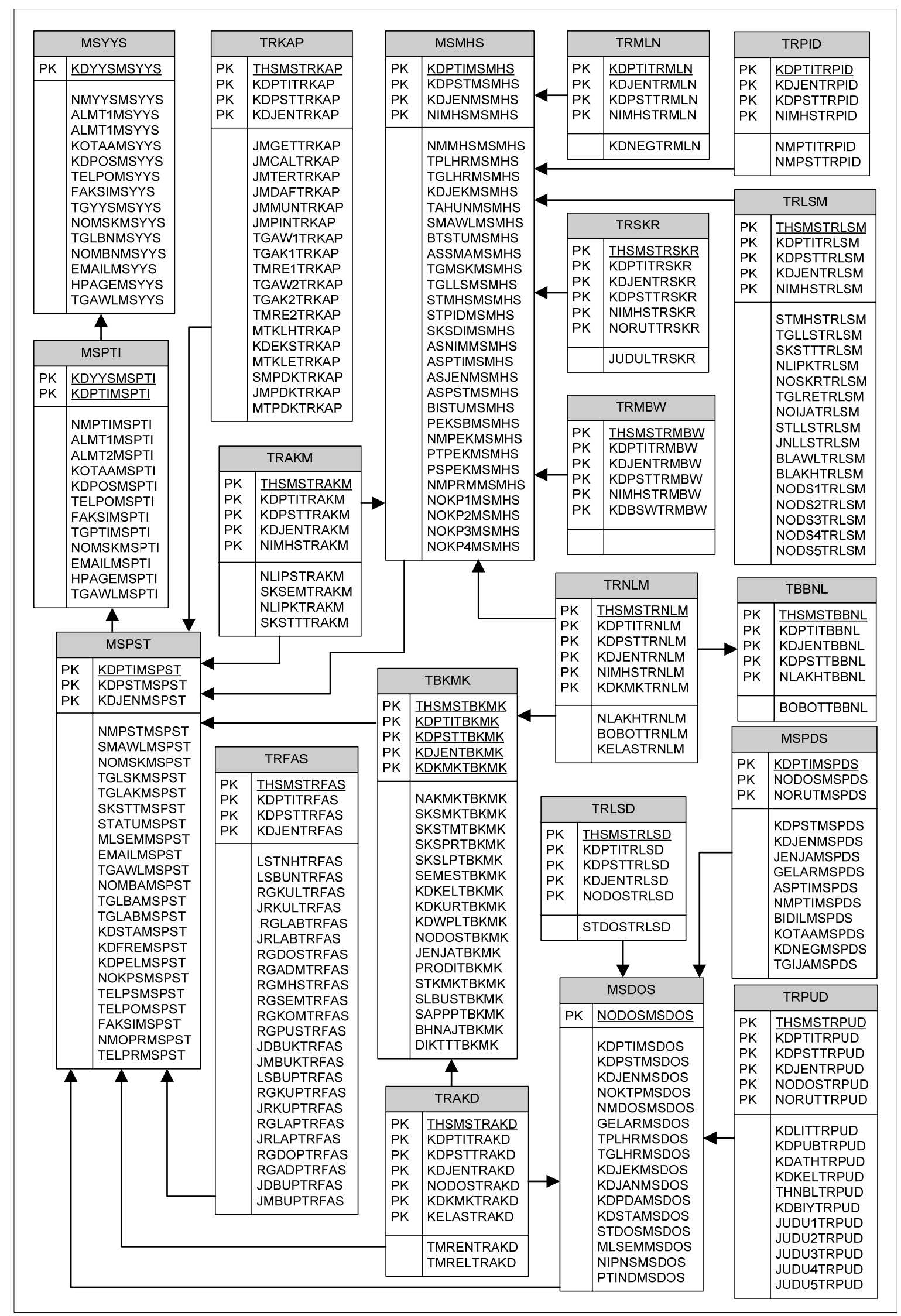

Gambar 2. Kelompok tabel yang saling berhubungan (ERD). 
Untuk modul Pendataan Data Badan Hukum, ada beberapa field yang akan didatakan pada modul ini, yaitu: Kode Badan Hukum, Nama Badan Hukum, Tanggal Awal Berdiri, Alamat, Kota, Kode Pos, Telepon, Faks, Nomor Akta Terakhir, Tanggal Akta Terakhir, Nomor Pengesahan, Tanggal Pengesahan, Email, dan Homepage untuk perguruan tinggi. Pada modul ini, ada fasilitas atau tombol untuk simpan data, reset data dan cetak laporan.

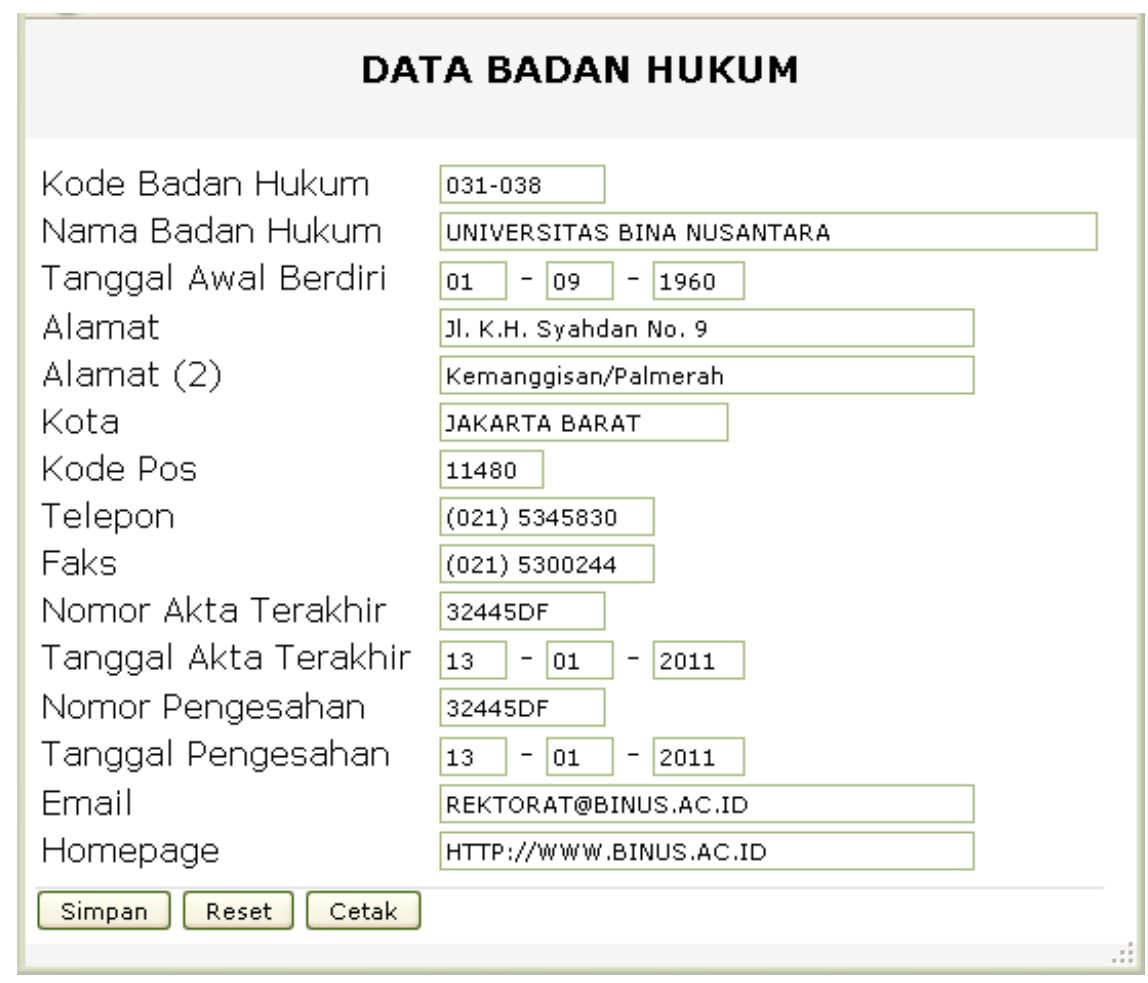

Gambar 3. UI modul Pendataan Data Badan Hukum.

Untuk modul Pendataan Dosen terdapat sub modul: Data Pribadi, Aktifitas Mengajar, Status Dosen, Riwayat Pendidikan dan Publikasi. Untuk penelitian ini, kami melampirkan tampilan UI sub modul Riwayat Pendidikan. Modul Update Data Mahasiswa terdapat sub modul: Data Pribadi, Aktifitas Kuliah, Nilai Semester, Status Mahasiswa, dan Mahasiswa Pindahan. untuk penelitian ini, kami melampirkan tampilan UI sub modul Nilai Semester. Modul Update Data Mata Kuliah terdapat sub modul: Master Mata Kuliah dan Kurikulum. Pada penelitian ini, kami melampirkan tampilan UI sub modul Kurikulum. Untuk modul Pendataan Dosen sub modul Riwayat Pendidikan, user akan mendatakan field yang terkait dengan riwayat pendidikan dosen. Pengguna dapat menambah data baru atau mengubah data yang sudah ada sebelumnya. 


\begin{tabular}{|c|c|c|c|c|c|c|c|c|c|c|}
\hline \multicolumn{11}{|c|}{ UPDATE DATA DOSEN } \\
\hline \multicolumn{2}{|c|}{ Data Pribadi } & \multicolumn{2}{|c|}{ Aktifitas Mengajar } & \multicolumn{2}{|c|}{ Status Dosen } & \multicolumn{2}{|c|}{ Riwayat Pendidikan } & \multicolumn{2}{|c|}{ Publikasi } & \\
\hline \multirow{3}{*}{\multicolumn{4}{|c|}{$\begin{array}{l}\text { Jurusan / Program Studi } \\
\text { NIDN Dosen } \\
\text { Nama Dosen }\end{array}$}} & \multirow{3}{*}{\multicolumn{6}{|c|}{$\begin{array}{l}241024 \text { - Teknik Informatika (S1) } \\
0210395713 \\
\text { KARTO ISKANDAR }\end{array}$}} & \\
\hline & & & & & & & & & & \\
\hline & & & & & & & & & & \\
\hline \multicolumn{11}{|c|}{ Riwayat Pendidikan } \\
\hline \multicolumn{3}{|c|}{ Tambah Data Baru } & \multicolumn{2}{|c|}{ Edit Data Lama } & & & & & & \\
\hline No & $\begin{array}{l}\text { JENJANG } \\
\text { STUDI }\end{array}$ & GELAR & $\begin{array}{l}\text { KODE } \\
\text { PT }\end{array}$ & $\begin{array}{l}\text { NAMA } \\
\text { PT }\end{array}$ & $\begin{array}{l}\text { BIDANG } \\
\text { ILMU }\end{array}$ & $\begin{array}{l}\text { KOTA } \\
\text { ASAL }\end{array}$ & \multicolumn{2}{|c|}{ IJAZAH } & \multicolumn{2}{|c|}{ PILIH } \\
\hline 1 & s1 & S.Kom. & 100167 & $\begin{array}{l}\text { FIK } \\
\text { Binus }\end{array}$ & $\begin{array}{l}\text { TEKNIK } \\
\text { INFORMATIKA }\end{array}$ & Jakarta & $25-06$ & 2002 & Ubah & Hapus \\
\hline 2 & $\mathrm{~s} 2$ & MM & 100167 & $\begin{array}{l}\text { FIM } \\
\text { Binus }\end{array}$ & $\begin{array}{l}\text { MAGISTER } \\
\text { MANAGEMENT }\end{array}$ & JAKARTA & $25-09$ & 2004 & Ubah & Hapus \\
\hline 3 & s3 & DR & 100167 & $\begin{array}{l}\text { FIK } \\
\text { Binus }\end{array}$ & $\begin{array}{l}\text { TEKNIK } \\
\text { INFORMATIKA }\end{array}$ & JAKARTA & $25-06$ & 2010 & Ubah & Hapus \\
\hline
\end{tabular}

Gambar 4. UI modul Pendataan Data Dosen.

Untuk modul Pendataan Mahasiswa sub modul Nilai Semester, dapat melihat informasi histori SKS Semester, SKS Kumulatif, IP Semester dan IP Kumulatif mahasiswa yang dipilih.

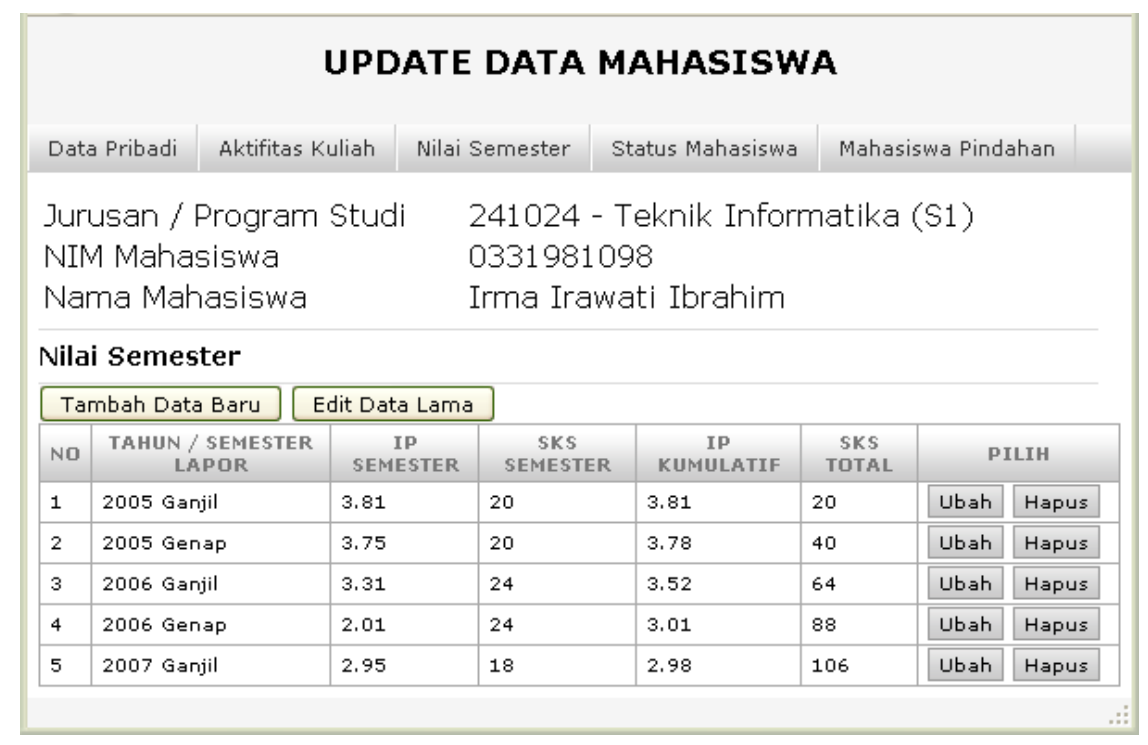

Gambar 5. UI Modul Pendataan Data Mahasiswa.

Untuk modul Pendataan Mata Kuliah sub modul Kurikulum, user dapat melihat histori dari status sebuah mata kuliah dan keterlibatannya dalam kurikulum, informasi yang di tampilkan dalam bentuk tabel, dengan informasi tahun semester kurikulum, sks, semester, kelompok mata kuliah, kurikulum, jenis mata kuliah apakah wajib atau pilihan, status aktif, status silabus, status bahan ajar, dan status diktat. 


\begin{tabular}{|c|c|c|c|c|c|c|c|c|c|c|c|c|}
\hline \multicolumn{13}{|c|}{ UPDATE DATA MATA KULIAH } \\
\hline \multicolumn{3}{|c|}{ Master Mata Kuliah } & Kurikulum & & & & & & & & & \\
\hline \multirow{3}{*}{\multicolumn{4}{|c|}{$\begin{array}{l}\text { Jurusan / Program Studi } \\
\text { Kode Mata Kuliah } \\
\text { Nama Mata Kuliah }\end{array}$}} & \multicolumn{9}{|c|}{241024 - Teknik Informatika (S1) } \\
\hline & & & & \multicolumn{9}{|c|}{ T0456 } \\
\hline & & & & \multicolumn{9}{|c|}{ Algoritma dan Metode Object Oriented Programming } \\
\hline \multicolumn{13}{|c|}{ Kurikulum } \\
\hline \multicolumn{3}{|c|}{ Tambah Data Baru } & \multicolumn{10}{|c|}{ Edit Data Lama } \\
\hline NO & $\begin{array}{l}\text { TAHUN / } \\
\text { SEMESTER }\end{array}$ & sks & SEMESTER & KELOMPOK & KURIKULUM & $\begin{array}{l}\text { WAJIB / } \\
\text { PILIHAN }\end{array}$ & STATUS & SILABUS & $\begin{array}{c}\text { BAHAN } \\
\text { AJAR }\end{array}$ & DIKTAT & & LIH \\
\hline 1 & $\begin{array}{l}2007 \\
\text { Ganjil }\end{array}$ & 2 & 03 & MPK & Institusi & Wajib & Aktif & Ү & T & $Y$ & Ubah & Hapus \\
\hline 2 & $\begin{array}{l}2007 \\
\text { Genap }\end{array}$ & 2 & 03 & MPK & Institusi & Wajib & Aktif & Ү & T & 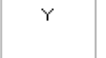 & Ubah & Hapus \\
\hline 3 & $\begin{array}{l}2008 \\
\text { Ganjil }\end{array}$ & 2 & 03 & MPK & Institusi & Wajib & Aktif & Y & $T$ & $Y$ & Ubah & Hapus \\
\hline 4 & $\begin{array}{l}2008 \\
\text { Genap }\end{array}$ & 2 & 03 & MPK & Institusi & Wajib & Aktif & Y & T & $Y$ & Ubah & Hapus \\
\hline 5 & $\begin{array}{l}2009 \\
\text { Ganjil }\end{array}$ & 2 & 03 & MPK & Institusi & Wajib & Aktif & Y & $T$ & $Y$ & Ubah & Hapus \\
\hline 6 & $\begin{array}{l}2009 \\
\text { Genap }\end{array}$ & 2 & 03 & MPK & Institusi & wajib & Aktif & Y & T & $Y$ & Ubah & Hapus \\
\hline
\end{tabular}

Gambar 6. UI Modul Pendataan Data Mata Kuliah.

Untuk modul Pendataan Komponen Nilai dapat didatakan komponen nilai, yaitu: nama komponen nilai dan bobot nilainya. Pada modul ini juga dapat dilihat semua komponen nilai yang ada dalam bentuk tabel. Sistem juga membantu menyajikan informasi total bobot komponen, sehingga user tidak perlu menghitung total bobot nilai.

\begin{tabular}{|c|c|c|c|c|c|c|}
\hline \multicolumn{7}{|c|}{ KOMPONEN NILAI } \\
\hline \multirow{2}{*}{\multicolumn{2}{|c|}{$\begin{array}{l}\text { Nama Komponen } \\
\text { Bobot nilai }\end{array}$}} & \multicolumn{3}{|c|}{ Nilai Ujian Akhir Semester } & & \\
\hline & & \multirow{2}{*}{\multicolumn{2}{|c|}{$40 \%$}} & & & \\
\hline Simpan & Reset & & & & & \\
\hline \multicolumn{7}{|c|}{ Detail Komponen Nilai } \\
\hline NO & \multicolumn{3}{|c|}{ NAMA KOMPONEN } & Вовот & \multicolumn{2}{|c|}{ PILIH } \\
\hline 1 & \multicolumn{3}{|c|}{ Nilai Ujian Akhir Semester } & 40 & Ubah & Hapus \\
\hline 2 & \multicolumn{3}{|c|}{ Nilai Ujian Tengah Semester } & 30 & Ubah & Hapus \\
\hline 3 & \multicolumn{3}{|c|}{ Nilai Tugas Mandiri } & 15 & Ubah & Hapus \\
\hline \multirow[t]{2}{*}{4} & \multicolumn{3}{|c|}{ Nilai Projek dan Presentasi } & 15 & Ubah & Hapus \\
\hline & \multicolumn{3}{|c|}{ Total Bobot Nilai } & 100 & & \\
\hline
\end{tabular}

Gambar 7. UI Modul Pendataan Data Komponen Nilai.

Untuk modul laporan IPK berguna untuk menyajikan informasi SKS Semester, IP Semester, SKS Kumulatif, dan IP Kumulatif per mahasiswa. Fitur dapat di filter per tahun semester, juga dapat 
mencari per NIM mahasiswa atau nama mahasiswa. Penyajian informasi dapat per halaman atau menampilkan semua informasi. Pada modul ini juga ada fasilitas untuk mencetak laporan IPK ini berdasarkan field yang telah dipilih.

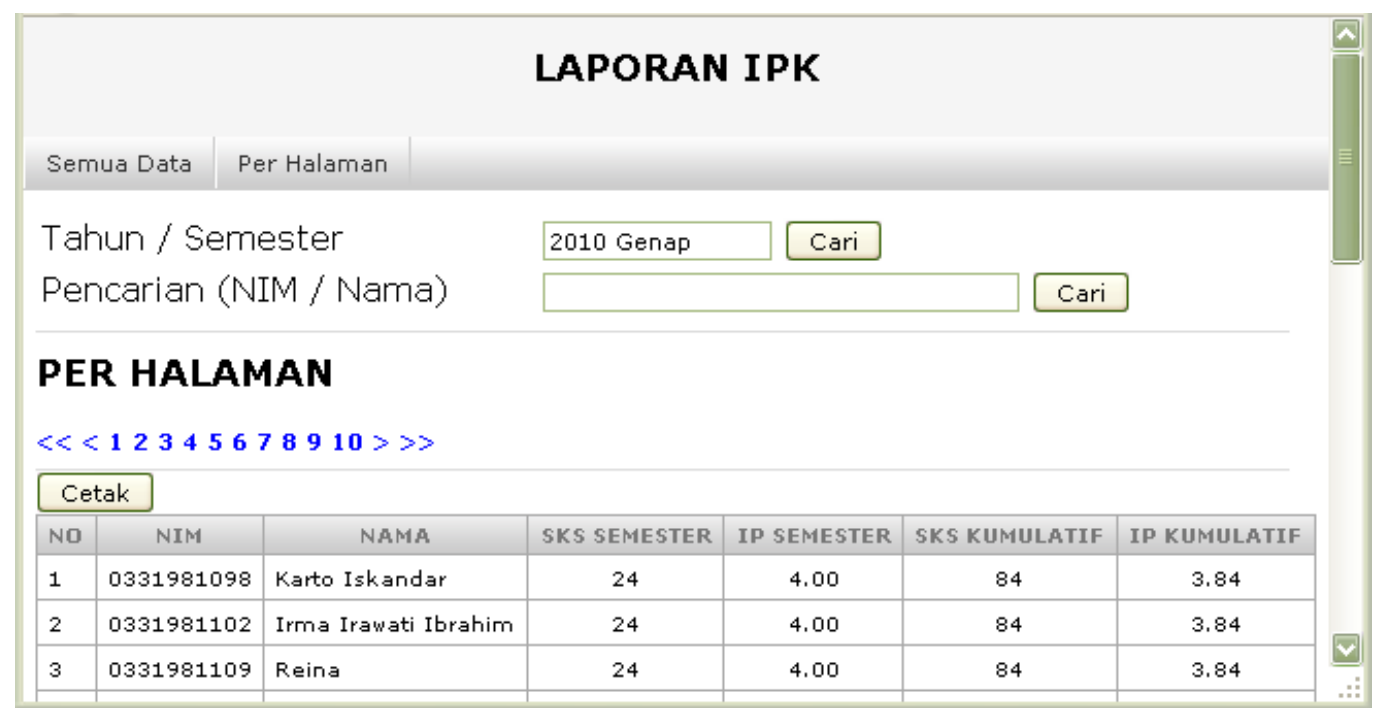

Gambar 8. UI Modul Laporan IPK.

\section{PENUTUP}

Perancangan sistem informasi akademis ini untuk mempermudah sebuah perguruan tinggi dalam menyajikan laporan Program Studi kepada DIKTI. Mengingat sistem informasi ini dibuat dengan mengikuti format pelaporan EPSBED, tabel dan field informasi yang dibutuhkan sudah disesuaikan. Sistem informasi ini dapat digunakan baik bagi perguruan tinggi yang sudah memiliki sistem informasi akademis ataupun bagi yang belum memanfaatkan teknologi informasi, karena sistem informasi ini menyimpan informasi dasar yang dibutuhkan oleh sebuah perguruan tinggi untuk dapat menjalankan aktifitas Program Studi. Perancangan ini masih dapat dikembangkan mengikuti perubahan yang terjadi sehubungan dengan kebutuhan perguruan tinggi dalam melakukan pelaporan EPSBED ke DIKTI.

\section{DAFTAR PUSTAKA}

Bennett, S., McRobb, S., dan Farmer, R., (2002). Object-Oriented Systems Analysis and Sesign , (2nd ed.). London: McGraw-Hill.

Satoto, Kodrat. (2009). Analisis Keamanan Sistem Informasi Akademik Berbasis Web Di Fakultas Teknik di Universitas Diponegoro. Semarang: Universitas Diponegoro.

Turban, Efrain. (2008). Introduction to Information System Enabling and Transforming Business, (2nd ed.) Singapore: John Willey \& Sons.

Wardana. (2010). Perancangan Sistem Informasi Akademik (SIM PT) Berbasis Database EPSBED. Bau-Bau: Universitas Muhammadiyah Buton. 